\title{
Stimulator of Interferon Genes Protein
}

National Cancer Institute

\section{Source}

National Cancer Institute. Stimulator of Interferon Genes Protein. NCI Thesaurus. Code C101588.

Stimulator of interferon genes protein ( $379 \mathrm{aa}, \sim 42 \mathrm{kDa}$ ) is encoded by the human TMEM173 gene. This proteinis involved in the modulation of both innate immune responses and signal transduction. 